\title{
Efficiency Enhancement of Multicrystalline Silicon Solar Cells by Inserting Two-Step Growth Thermal Oxide to the Surface Passivation Layer
}

\author{
Shun Sing Liao, Yueh Chin Lin, Chuan Lung Chuang, and Edward Yi Chang \\ Department of Materials Science and Engineering, National Chiao Tung University, 1001 Ta Hsueh Road, Hsin-Chu 30010, Taiwan \\ Correspondence should be addressed to Edward Yi Chang; edc@mail.nctu.edu.tw
}

Received 6 June 2017; Revised 6 August 2017; Accepted 7 September 2017; Published 8 October 2017

Academic Editor: Giulia Grancini

Copyright (C) 2017 Shun Sing Liao et al. This is an open access article distributed under the Creative Commons Attribution License, which permits unrestricted use, distribution, and reproduction in any medium, provided the original work is properly cited.

\begin{abstract}
In this study, the efficiency of the multicrystalline was improved by inserting a two-step growth thermal oxide layer as the surface passivation layer. Two-step thermal oxidation process can reduce carrier recombination at the surface and improve cell efficiency. The first oxidation step had a growth temperature of $780^{\circ} \mathrm{C}$, a growth time of $5 \mathrm{~min}$, and with $\mathrm{N}_{2} / \mathrm{O}_{2}$ gas flow ratio $12: 1$. The second oxidation had a growth temperature of $750^{\circ} \mathrm{C}$, growth time of $20 \mathrm{~min}$, and under pure $\mathrm{N}_{2}$ gas environment. Carrier lifetime was increased to $15.45 \mu \mathrm{s}$, and reflectance was reduced $0.52 \%$ using the two-step growth method as compared to the conventional one-step growth oxide passivation method. Consequently, internal quantum efficiency of the solar cell increased $4.1 \%$, and conversion efficiency increased $0.37 \%$. These results demonstrate that the two-step thermal oxidation process is an efficient way to increase the efficiency of the multicrystalline silicon solar cells.
\end{abstract}

\section{Introduction}

Many methods have been proposed to improve multicrystalline silicon (mc-Si) solar cell efficiency. The mc-Si wafers usually contain significant amounts of defects and impurities which affect minority carrier lifetime and limit multicrystalline solar cell efficiency. Solar cell efficiency can also be affected by surface recombination of the carriers. Macdonald et al. [1] and Krotkus et al. [2] successfully enhanced mc-Si solar cell efficiency using several methods, including dry texturing, gettering, selective emitters, hydrogen surface passivation, and using of silicon nitride $\left(\mathrm{SiN}_{\mathrm{x}}\right)$ passivation layer on the emitter surface.

An enhanced lifetime of the photon-generated carriers has also been realized using $\mathrm{SiO}_{2}, \mathrm{SiN}_{\mathrm{x}}$, and $\mathrm{SiCN}_{\mathrm{x}}$ films as surface passivation layers [3-5]. Jana et al. [6] showed the interface trap density $\left(D_{\mathrm{it}}\right)\left(2.52 \times 10^{11} \mathrm{~cm}^{-2} \mathrm{eV}^{-1}\right)$ at the $\mathrm{SiNx} / \mathrm{Si}$ interface. The growth of a high-quality $\mathrm{SiO}_{2}$ layer with low interface trap density $\left(D_{\mathrm{it}}\right)$ on silicon is an effective surface passivation method for the solar cells to further improve cell efficiency [7-9]. Derbali and Ezzaouia [10] reported that thermal $\mathrm{SiO}_{2}$ film is an effective surface passivation layer for highly phosphorus-doped silicon wafers. Ohtsuka et al. [11] showed the $D_{\text {it }}\left(1.0 \times 10^{11} \mathrm{~cm}^{-2} \mathrm{eV}^{-1}\right)$ at the $\mathrm{SiO}_{2} / \mathrm{Si}$ interface. Comparing $D_{\text {it }}$ of without thermal oxidation (TO) and thermal oxidation (TO) was from $2.52 \times 10^{11} \mathrm{~cm}^{-2} \mathrm{eV}^{-1}$ to $1.0 \times 10^{11} \mathrm{~cm}^{-2} \mathrm{eV}^{-1}$. Kotipallia et al. [12] showed the $D_{\mathrm{it}}$ reduction at the silicon/dielectric interface by using hydrogen gas annealing to reduce the dangling bonds. Schultz et al. [13] showed the influence of thermal oxidation temperature on the $D_{\text {it }}$ of the interface. High temperature $\left(>1000^{\circ} \mathrm{C}\right)$ dry oxidation growth of the $\mathrm{SiO}_{2}$ film results in low $D_{\text {it }}\left(10^{10} \mathrm{~cm}^{-2} \mathrm{eV}^{-1}\right)$ at the $\mathrm{SiO}_{2} / \mathrm{Si}$ interface, but the process may deteriorate bulk Si quality and reduce bulk carrier lifetime. Reducing the growth temperature to $800^{\circ} \mathrm{C}$ with wet oxidation $\left(\mathrm{Si}+2 \mathrm{H}_{2} \mathrm{O} \rightarrow \mathrm{SiO}_{2}+2 \mathrm{H}_{2}\right)$ can increase the bulk carrier lifetime. The efficiency of the sample annealed at high temperature $\left(1050^{\circ} \mathrm{C}\right)$ was $17.20 \%$, while at lower temperature $\left(800^{\circ} \mathrm{C}\right)$ was $17.8 \%$. The open circuit voltage increased about $16 \mathrm{mV}$ at lower temperature, this is because the low temperature $\left(800^{\circ} \mathrm{C}\right)$ passivation has higher bulk lifetime than the high temperature $\left(1050^{\circ} \mathrm{C}\right)$ passivation. But using this temperature with dry oxidation process has not been studied. Chen et al. [14] and Hiroshige et al. [15] 


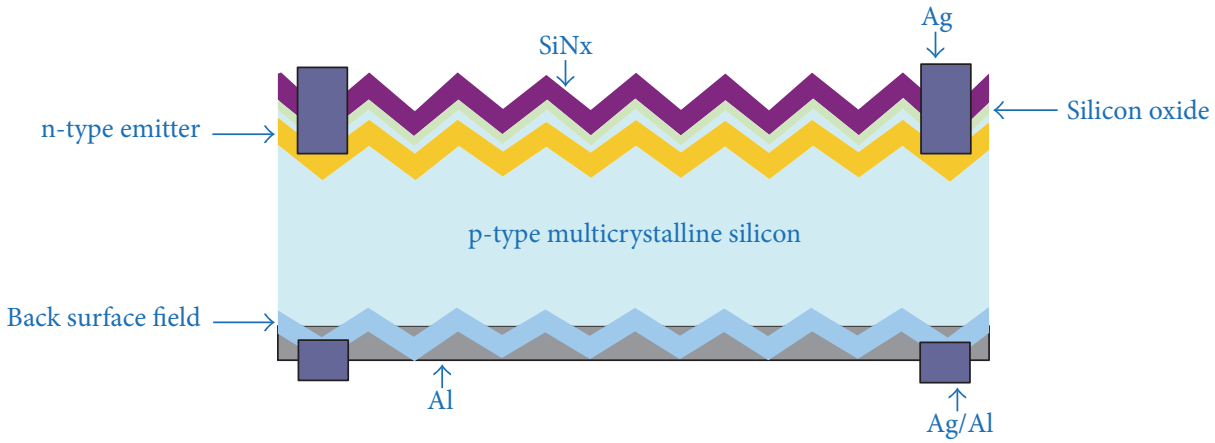

(a)

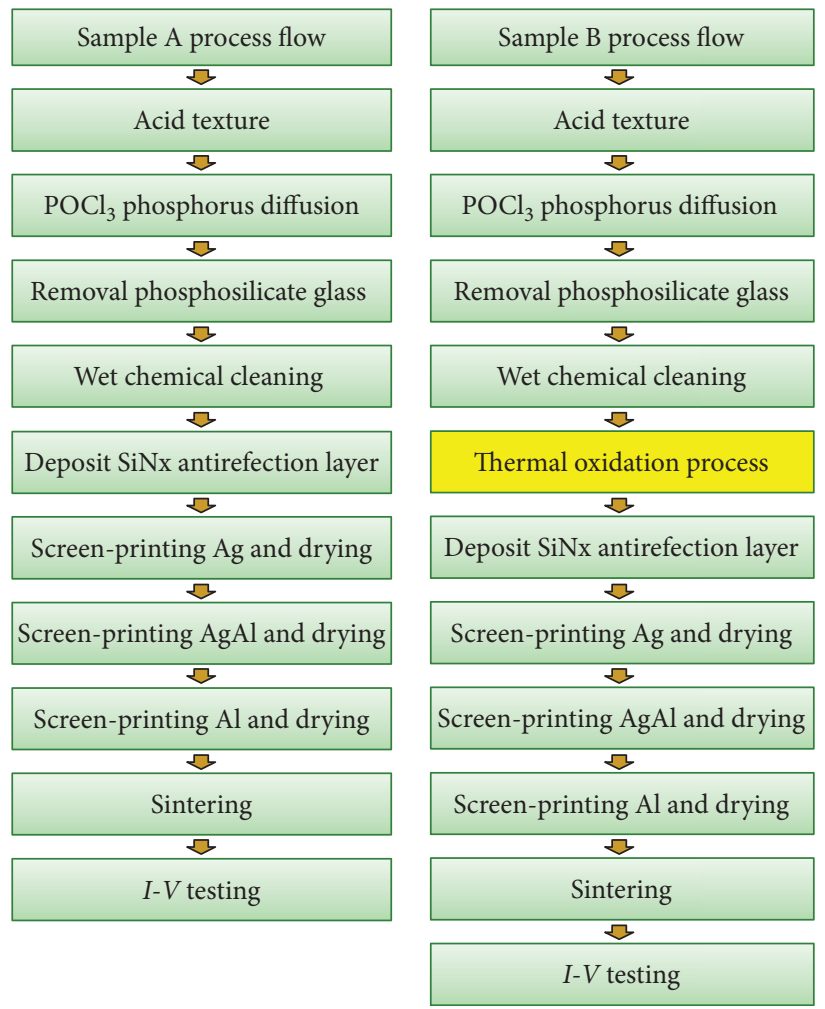

(b)

Figure 1: (a) The cross section of the completed multicrystalline silicon solar cell and (b) fabrication process flow of the multicrystalline silicon solar cells.

showed that low temperature grown $\mathrm{SiO}_{2}$ layers also have low interface $D_{\text {it }}$ with Si wafers when used for surface passivation. Cai and Rohatgi [16] showed that the most effective annealing temperature after PECVD for multicrystalline solar cell wafers was $650^{\circ} \mathrm{C}$ to $750^{\circ} \mathrm{C}$.

Narasimha and Rohatgi [17] showed that growth of the $\mathrm{SiO}_{2}$ layer by rapid thermal oxidation had a low surface recombination velocity $(S=10 \mathrm{~cm} / \mathrm{s})$ on the silicon surface, and Chen et al. $[18,19]$ showed that a $\mathrm{SiO}_{2}$ layer deposited on Si wafer by PECVD followed by rapid thermal annealing could produce lower $S$ and higher carrier lifetime. In this work, the use of lower temperature $\left(750^{\circ} \mathrm{C}-780^{\circ} \mathrm{C}\right)$ two-step grown $\mathrm{SiOx}$ film as passivation layers using dry oxidation $\left(\mathrm{Si}+\mathrm{O}_{2} \rightarrow \mathrm{SiO}_{2}\right)$ process was performed and studied. The goal was to improve bulk Si crystalline quality and the bulk carrier lifetime after lower temperature thermal oxidation process and to compare the crystalline quality and carrier lifetime with high temperature $\left(>1000^{\circ} \mathrm{C}\right)$ grown oxide. The efficiency enhancement of the mc-Si solar cells was observed after by applying silicon oxide passivation layer grown by two-step thermal oxidation (TO) method. The TO process influence on mc-Si solar cell electrical properties is also investigated and found that by proper design of the oxidation process, the solar cell electrical properties can be effectively improved.

\section{Experimental}

Figure 1(a) shows the sample structure of the solar cell in this study, fabricated on a p-type mc-Si wafer, and Figure 1(b) 


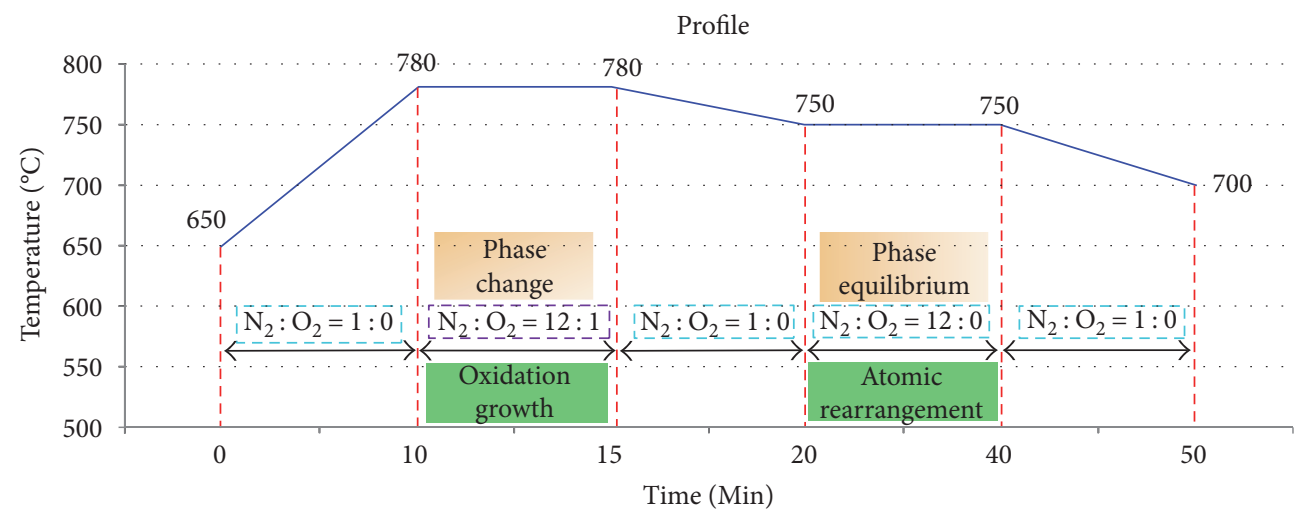

Figure 2: Two-step thermal oxidation temperature versus time profile.

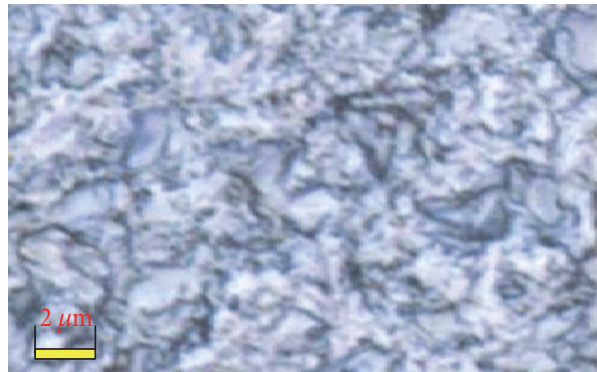

(a)

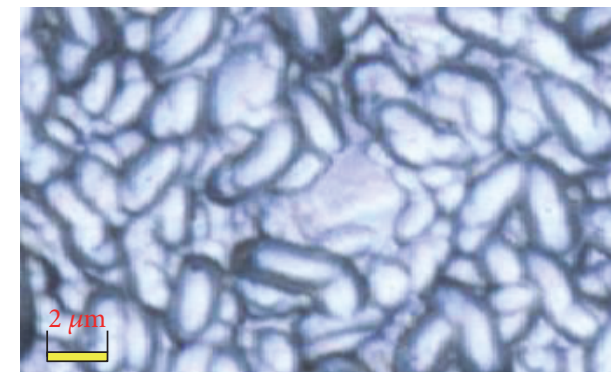

(b)

FIGURE 3: Plane-view optical microscope images of the surface morphologies (a) preetching and (b) postetching.

shows the fabrication process, consisting of $\mathrm{Al} / \mathrm{p}-\mathrm{Si} / \mathrm{n}-\mathrm{Si} /$ $\mathrm{SiO} 2 / \mathrm{SiNx} / \mathrm{Ag}$ layers. The fabrication process commenced with acid texturing, followed by a shallow diffusion layer formed by $\mathrm{POCl}_{3}$ phosphorus diffusion process, resulting in $82 \Omega /$ sq sheet resistance. The phosphosilicate glass was then removed by the wet chemical method, and each wafer was divided into sample A (without TO process) and sample B (with TO process). A high-quality batch-type quartz tube furnace system was used for the two-step TO process, with a temperature profile as shown in Figure 2 to grow oxide on the wafer. The first oxidation step had a growth temperature of $780^{\circ} \mathrm{C}$, with growth time $5 \mathrm{~min}$, and $\mathrm{N}_{2} / \mathrm{O}_{2}$ gas flow ratio $12: 1$. The second oxidation step had a growth temperature of $750^{\circ} \mathrm{C}$, growth time $20 \mathrm{~min}$, and with pure $\mathrm{N}_{2}$ gas environment. To improve incident light absorption, PECVD SiNx film was deposited on both samples after oxidation.

Screen printing was employed to deposit Ag glue on the front side SiNx layer and AgAl glue on the back side of the wafer, with an intermediate drying process. Finally, the samples were annealed at $750-850^{\circ} \mathrm{C}$ to complete the solar cell fabrication.

\section{Results and Discussion}

Texturizing of the solar cell surface was performed with $\mathrm{HF} / \mathrm{HNO}_{3} / \mathrm{H}_{2} \mathrm{SO}_{4}$ and deionized water mixture to form a randomly oriented micron-size texture. Figures $3(\mathrm{a})$ and 3(b) show plane-view optical microscopic (OM) images of pre- and postetched wafer surfaces at 100x magnification.

Schmidt and Aberle [20] showed that the carrier lifetime can be measured by the microwave photoconductance decay (Semilab system, Model WT-2000). Both samples were measured; Figures 4(a) and 4(b) show the carrier lifetime for samples $\mathrm{A}$ and $\mathrm{B}$ (with and without oxide layer, resp.), and average carrier lifetimes were 5.55 and $21 \mu$ s, respectively. Thus, carrier lifetime was significantly improved by the proposed TO process. Lee and Glunz [21] showed that improve carrier lifetime also improved the solar cell efficiency.

Surface reflectance was measured using a UV-VIS-NIR spectrophotometer (HMT, Model MFS-630) in the spectral range $350-1050 \mathrm{~nm}$; after SiNx film deposition are shown in Figure 5(a) test data and summarized in Table 1. Average reflectances were $3.28 \%$ and $2.76 \%$ for samples $A$ and $\mathrm{B}$, respectively; sample B (with TO) had a lower reflectance of $0.52 \%$. Lee et al. [22] showed that the solar cell absorption band was in the range $400-1200 \mathrm{~nm}$. Thus, the lower average reflectance of sample B results in higher efficiency of the solar cell. Meziani et al. [23] showed that reflectance were $2.77 \%$ and $0.94 \%$ at $600-800 \mathrm{~nm}$ range for $\mathrm{SiNx}$ and $\mathrm{SiNx} / \mathrm{SiO}_{2}$ passivation, respectively. The refractive index $(n)$ of $\mathrm{SiNx}$ and $\mathrm{SiO}_{2}$ were 2 and 1.45 , respectively. Thus, adding $\mathrm{SiO}_{2}$ film of low refractive index $(n)$ can decrease reflectance of the light (Figure 6).

Internal quantum efficiency (IQE) was measured using a Solar Cell Scan 100 quantum efficiency measurement system 


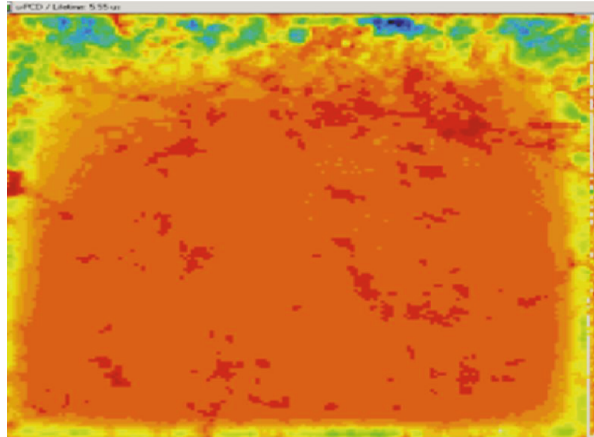

(a)

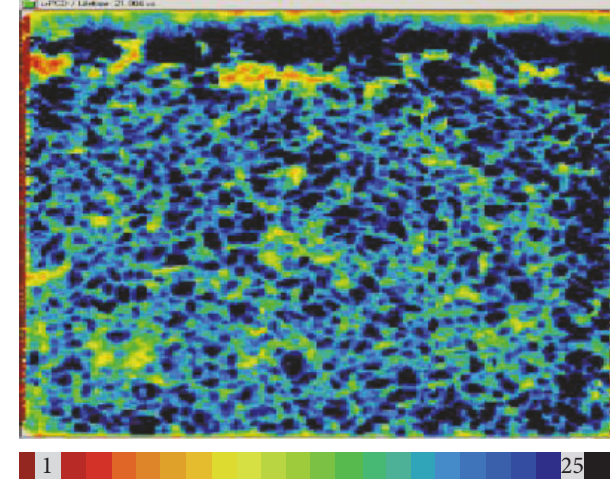

(b)

FIgURE 4: Carrier lifetime maps with respect to time: (a) sample A (without thermal oxidation) average carrier lifetime was $5.5 \mu$ s and (b) sample B (with thermal oxidation) average carrier lifetime was $21 \mu \mathrm{s}$.

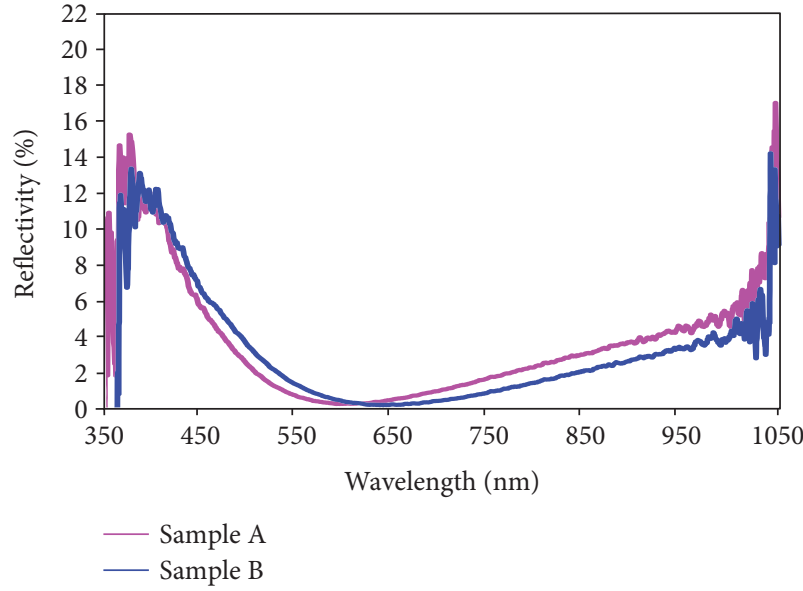

(a)

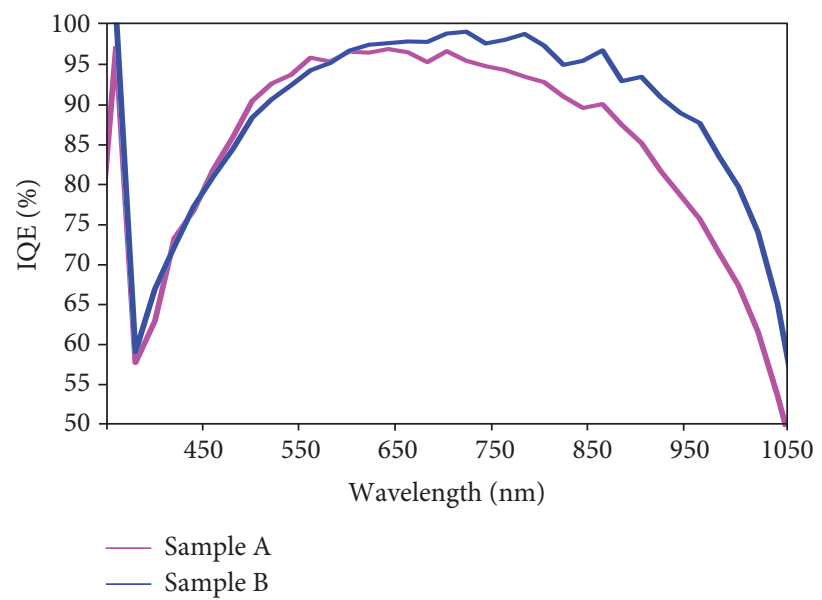

(b)

FIGURE 5: The solar cell data (a) reflectance and (b) internal quantum efficiency (IQE) curves.

TABLE 1: Measurement results of the samples of the multicrystalline silicon solar cells.

\begin{tabular}{lccccc}
\hline \multirow{2}{*}{ Samples } & \multirow{2}{*}{ Carrier lifetime $(\mu \mathrm{s})$} & Reflectance $(\%)$ & IQE $(\%)$ & Efficiency $(\%)$ & \multicolumn{2}{c}{$I-V$ characterization } & $V_{\mathrm{OC}}(\mathrm{V})$ & $I_{\mathrm{SC}}(\mathrm{A})$ \\
\hline $\mathrm{A}$ & 5.55 & 3.28 & 84.62 & 17.27 & 0.623 \\
$\mathrm{~B}$ & 21 & 2.76 & 88.72 & 17.64 & 8.59 \\
\hline
\end{tabular}

(Model QEX10) at 350-1050 nm spectral range as shown in Figure 5(b), and the results are summarized in Table 1. Average IQE data were $84.62 \%$ and $88.72 \%$ for samples A and B, respectively, an increase of $4.1 \%$ for sample $B$.

The IQE of a solar cell with and without TO passivation can provide information on the passivation effect from the surface and bulk recombinations. For wavelengths $<800 \mathrm{~nm}$, IQE provides information related to $S$, while for wavelengths $>800 \mathrm{~nm}$, IQE provides information related to $\tau$. Figure 5(b) shows that for sample B, IQE increased mostly in the spectral range $600-1050 \mathrm{~nm}$, with its reflectance decrease over that range due to the $\mathrm{SiOx} / \mathrm{SiNx}$ antireflection coating. Thus, the treatments effectively increased light absorption of the solar cell.

Thus, sample B has enhanced IQE over sample A. Since the major IQE enhancement is in the $600-1050 \mathrm{~nm}$ range, it is mainly due to reduced reflectance.

Morales-Acevedo and Pérez-Sánchez [24] showed that improve efficiency of without $\mathrm{TO}$ and with $\mathrm{TO}\left(\mathrm{SiO}_{2}\right)$ were $11.37 \%$ and $11.53 \%$, respectively, and conversion efficiency increased $0.16 \%$. Mack et al. [25] showed that improve efficiency of without $\mathrm{TO}$ and with $\mathrm{TO}\left(\mathrm{SiO}_{2}\right)$ were $17.8 \%$ and $18.1 \%$, respectively, and conversion efficiency increased $0.3 \%$. Gatz et al. [26] showed that improve efficiency of back 

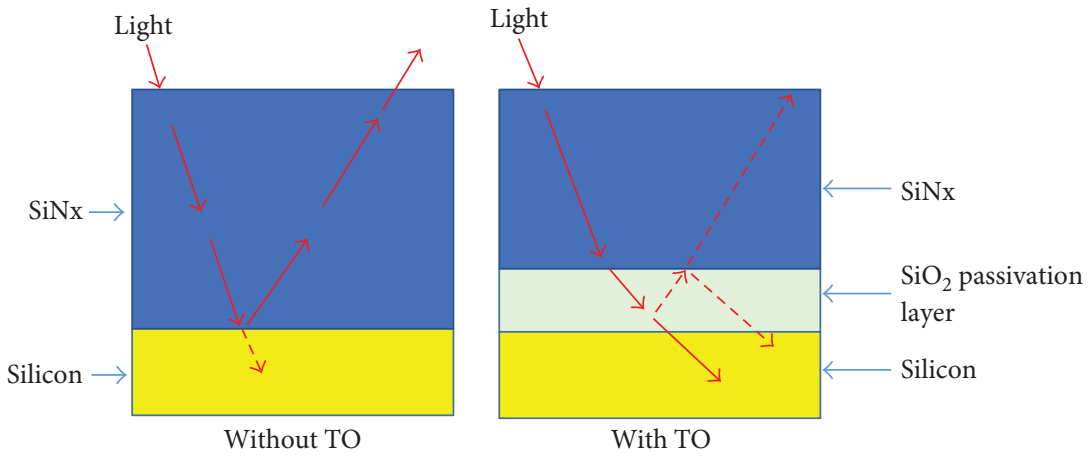

Figure 6: Lower average reflectance mechanism.

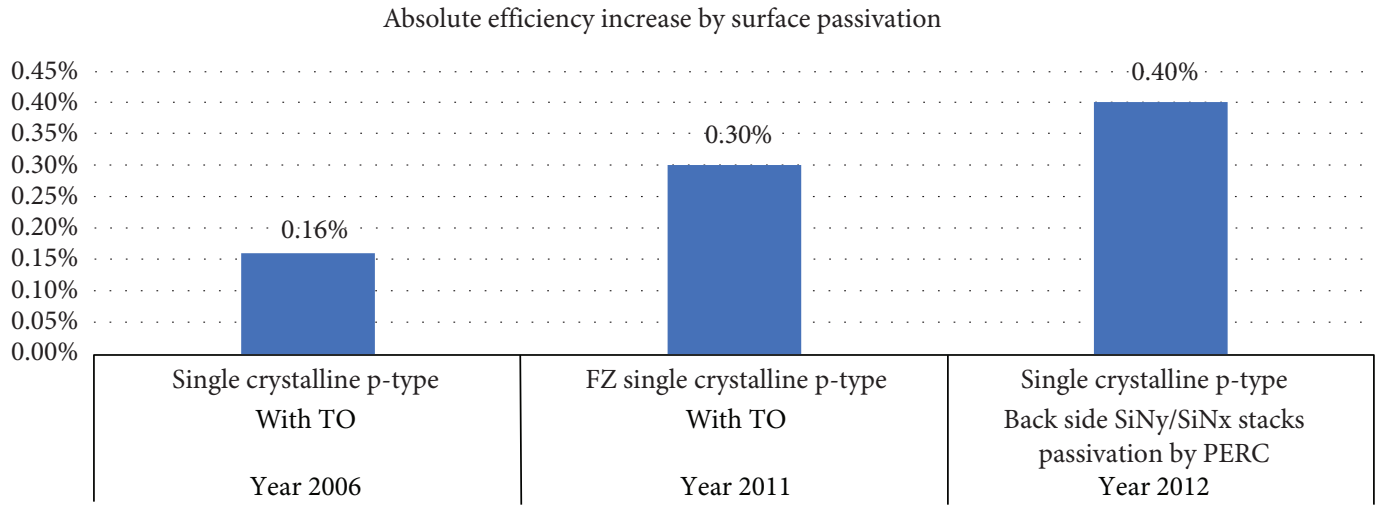

Figure 7: Absolute efficiency increase by surface passivation in single crystalline p-type [24-26].

side $\mathrm{SiNy} / \mathrm{SiNx}$ stacks for the surface passivation was from $17.9 \%$ to $18.3 \%$, and conversion efficiency increased $0.4 \%$. The absolute efficiency gain by surface passivation in single crystalline from 2006 to 2012 was only $0.16 \% \sim 0.4 \%$ as shown in Figure 7 [24-26]. Thus, the increase of $0.4 \%$ is quite significant.

In this study, the $I-V$ characteristics of the samples were measured under illumination (Berger Lichttechnik, Model PSS $10 \mathrm{II})$, as summarized in Table 1. The efficiencies of sample A and sample B were $17.27 \%$ and $17.64 \%$, respectively. The conversion efficiency increase of $0.37 \%$ is significant. Sample B efficiency was $2.14 \%$ higher than that of sample $\mathrm{A}$, open circuit voltage $\left(V_{\mathrm{oc}}\right)$ was $1.44 \%$ higher, and short circuit current $\left(I_{\mathrm{sc}}\right)$ was $1.51 \%$ higher than that of sample A. Thus, the proposed two-step TO process is an effective way to increase mc-Si solar cell efficiency and related characteristics.

\section{Conclusions}

This study successfully demonstrates enhanced multicrystalline silicon solar cell efficiency by inserting a two-step growth thermal oxide layer to the SiNx passivation layer. The first oxidation step had a growth temperature of $780^{\circ} \mathrm{C}$, growth time of $5 \mathrm{~min}$, and with $\mathrm{N}_{2} / \mathrm{O}_{2}$ gas flow ratio $12: 1$; the second step had a growth temperature of $750^{\circ} \mathrm{C}$, growth time of $20 \mathrm{~min}$, and under pure $\mathrm{N}_{2}$ gas environment. The wafers were annealing at the temperature of $750^{\circ} \mathrm{C}$ to $780^{\circ} \mathrm{C}$ after the dry oxidation process. The goal was to improve bulk Si crystalline quality and bulk carrier lifetime after thermal oxidation. The proposed two-step process retained thin oxide layers, preventing effect formation of SiNx layer optical characteristics, which can reduce efficiency.

The mc-Si solar cell efficiency improved to $17.64 \%$ from after inserting two-step growth thermal oxide layer between the p-type $\mathrm{Si} / \mathrm{n}$-type $\mathrm{Si}$ and $\mathrm{SiN}_{\mathrm{x}}$ passivation layer. The resultant silicon oxide layer increased the absorption of the light in the spectral range $400-1050 \mathrm{~nm}$ by $4.1 \%$ and thus improved the total absolute efficiency of the mc-Si solar cell.

\section{Conflicts of Interest}

The authors declare that they have no conflicts of interest.

\section{Acknowledgments}

This work was sponsored by TSMC, NCTU-UCB I-RiCE program and Ministry of Science and Technology, Taiwan, under no. MOST106-2911-I-009-301.

\section{References}

[1] D. H. Macdonald, A. Cuevas, M. J. Kerr et al., "Texturing industrial multi-crystalline silicon solar cells," Solar Energy, vol. 76, no. 1-3, pp. 277-283, 2004. 
[2] A. Krotkus, K. Grigoras, V. Paebutas et al., "Efficiency improvement by porous silicon coating of multi-crystalline solar cells," Solar Energy Materials and Solar Cells, vol. 45, no. 3, pp. 267-273, 1997.

[3] G. Dingemans, M. M. Mandoc, S. Bordihn, M. C. M. Van de Sanden, and W. M. M. Kessels, "Effective passivation of Si surfaces by plasma deposited SiOx/a-SiNx:H stacks," Applied Physics Letters, vol. 98, no. 22, article 222102, 2011.

[4] H. Mäckel and R. Lüdemann, "Detailed study of the composition of hydrogenated SiNx layers for high-quality silicon surface passivation," Journal of Applied Physics, vol. 92, p. 2602, 2002.

[5] Y. Awad, M. A. El Khakani, M. Scarlete et al., "Structural analysis of silicon carbon nitride films prepared by vapor transport-chemical vapor deposition," Journal of Applied Physics, vol. 107, article 033517, 2010.

[6] T. Jana, S. Mukhopadhyay, and S. Ray, "Low temperature silicon oxide and nitride for surface passivation of silicon solar cells," Solar Energy Materials and Solar Cells, vol. 71, no. 2, pp. 197-211, 2002.

[7] M. A. Green, "Limiting efficiency of bulk and thin-film silicon solar cells in the presence of surface recombination," Progress in Photovoltaics, vol. 7, p. 327, 1999.

[8] M. J. Kerr and A. Cuevas, "Recombination at the interface between silicon and stoichiometric plasma silicon nitride," Semiconductor Science and Technology, vol. 17, p. 35, 2002.

[9] T. Jana, S. Mukhopadhyay, and S. Ray, "Low temperature silicon oxide and nitride for surface passivation of silicon solar cells," Solar Energy Materials and Solar Cells, vol. 71, p. 197, 2002.

[10] L. Derbali and H. Ezzaouia, "Vanadium-based antireflection coated on multi-crystalline silicon acting as a passivating layer," Solar Energy, vol. 86, no. 5, pp. 1504-1510, 2012.

[11] H. Ohtsuka, T. Uematsu, and T. Warabisako, "Numerical analysis of field-effect surface passivation for solar cells," Solar Energy Materials and Solar Cells, vol. 44, no. 1, pp. 79-98, 1996.

[12] R. Kotipallia, R. Delamare, O. Poncelet, X. Tang, L. A. Francis, and D. Flandre, "Passivation effects of atomic-layer-deposited aluminum oxide," EPJ Photovoltaics, vol. 4, article 45107, 2013.

[13] O. Schultz, S. W. Glunz, and G. P. Willeke, "Multicrystalline silicon solar cells exceeding 20\% efficiency," Progress in Photovoltaics: Research and Applications, vol. 12, p. 553, 2004.

[14] Z. Chen, K. Yasutake, A. Doolittle, and A. Rohatgi, "Record low $\mathrm{SiO} 2 / \mathrm{Si}$ interface state density for low temperature oxides prepared by direct plasma-enhanced chemical vapor deposition," Applied Physics Letters, vol. 63, p. 2117, 1993.

[15] Y. Hiroshige, S. Higashi, K. Matsumoto, and S. Miyazaki, "Formation of high-quality $\mathrm{SiO} 2$ and $\mathrm{SiO} 2 / \mathrm{Si}$ interface by thermal-plasma-jet-induced millisecond annealing and postmetallization annealing," Japanese Journal of Applied Physics, vol. 49, article 08JJ01, 2010.

[16] L. Cai and A. Rohatgi, "Effect of post-PECVD photo-assisted anneal on multicrystalline silicon solar cells," IEEE Transactions on Electron Devices, vol. 44, no. 1, pp. 97-103, 1997.

[17] S. Narasimha and A. Rohatgi, "Effective passivation of the low resistivity silicon surface by a rapid thermal oxide/plasma silicon nitride stack," Applied Physics Letters, vol. 72, no. 15, pp. 1872-1874, 1998.

[18] Z. Chen, S. K. Pang, K. Yasutake, and A. Rohatgi, "Plasmaenhanced chemical-vapor-deposited oxide for low surface recombination velocity and high effective lifetime in silicon," Journal of Applied Physics, vol. 74, no. 4, pp. 2856-2859, 1993.

[19] Z. Chen, A. Rohatgi, R. O. Bell, and J. P. Kalejs, "Defect passivation in multi-crystalline-Si materials by plasma-enhanced chemical vapor deposition of $\mathrm{SiO} 2 / \mathrm{SiN}$ coatings," Applied Physics Letters, vol. 65, no. 16, pp. 2078-2080, 1994.

[20] J. Schmidt and A. G. Aberle, "Accurate method for the determination of bulk minority-carrier lifetimes of monoand multi-crystalline silicon wafers," Journal of Applied Physics, vol. 81, no. 9, pp. 6186-6199, 1997.

[21] J. Y. Lee and S. W. Glunz, "Investigation of various surface passivation schemes for silicon solar cells," Solar Energy Materials and Solar Cells, vol. 90, no. 1, pp. 82-92, 2006.

[22] D. Y. Lee, H. H. Lee, J. Y. Ahn et al., "A new back surface passivation stack for thin crystalline silicon solar cells with screen-printed back contacts," Solar Energy Materials and Solar Cells, vol. 95, no. 1, pp. 26-29, 2011.

[23] S. Meziani, A. Moussi, L. Mahiou, and R. Outemzabet, "Effect of thermal annealing on double anti reflection coating $\mathrm{SiNx} / \mathrm{SiO}_{2}$," in 2015 3rd International Renewable and Sustainable Energy Conference (IRSEC), 2015.

[24] A. Morales-Acevedo and G. F. Pérez-Sánchez, "Silicon solar cells using silicon oxynitride $\left(\mathrm{SiO}_{2}: \mathrm{N}\right)$ for emitter surface passivation," in 2006 IEEE 4th World Conference on Photovoltaic Energy, pp. 1253-1255, 2006.

[25] S. Mack, C. Wufka, A. Wolf, U. Belledin, D. Scheffler, and D. Biro, "Surface passivation of phosphorus-diffused emitters by inline thermal oxidation," Energy Procedia, vol. 8, pp. 343-348, 2011.

[26] S. Gatz, T. Dullweber, V. Mertens, F. Einsele, and R. Brendel, "Firing stability of SiNy/SiNx stacks for the surface passivation of crystalline silicon solar cells," Solar Energy Materials and Solar Cells, vol. 96, pp. 180-185, 2012. 

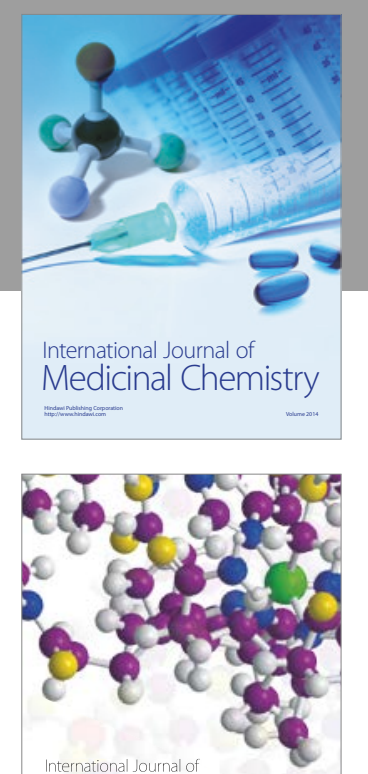

Carbohydrate Chemistry

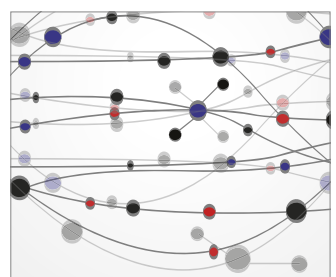

The Scientific World Journal
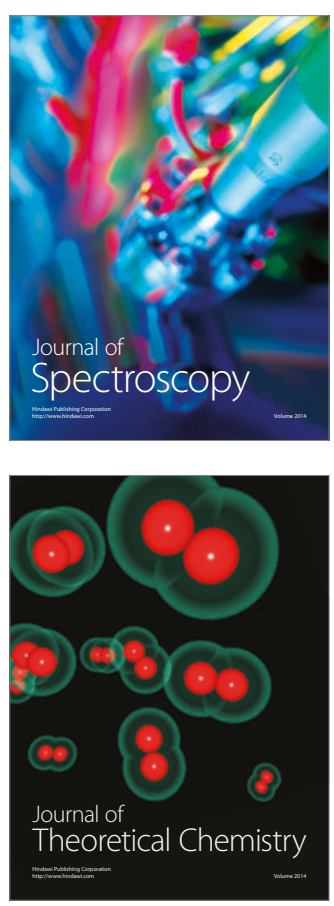
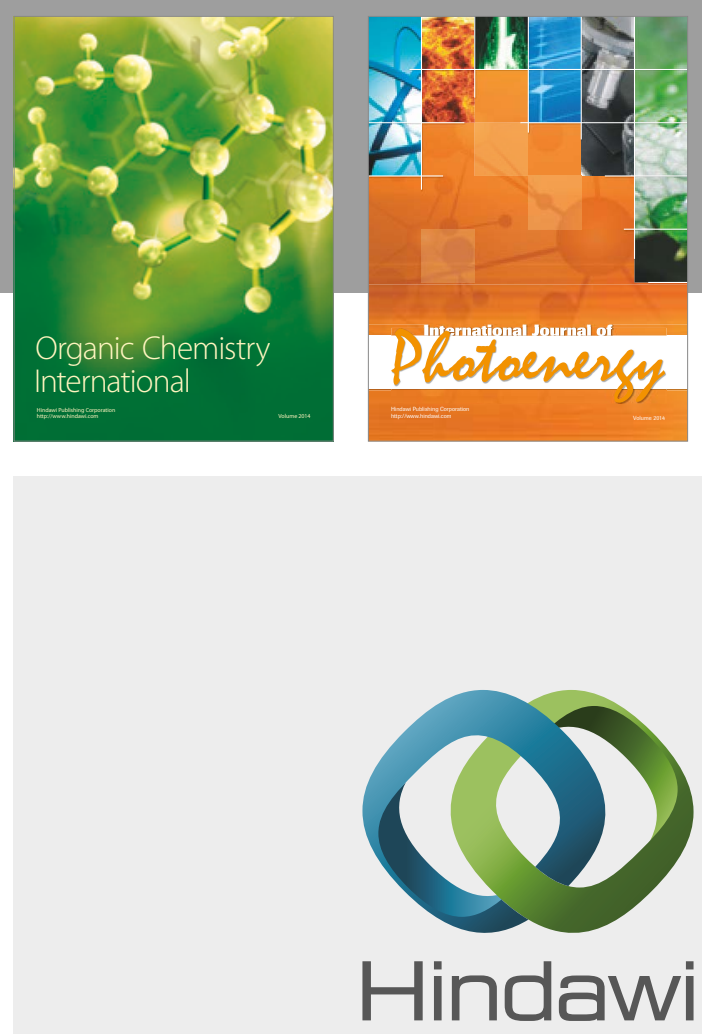

Submit your manuscripts at

https://www.hindawi.com

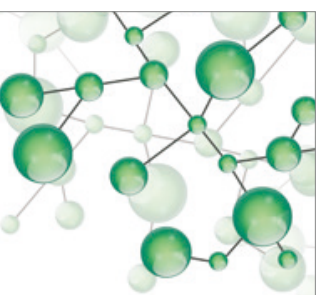

International Journal of

Inorganic Chemistry

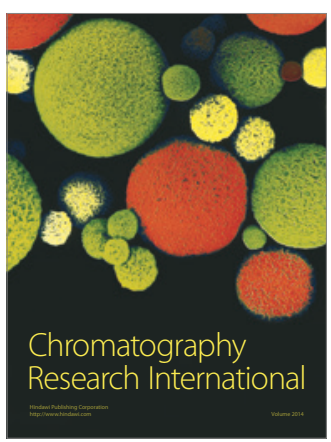

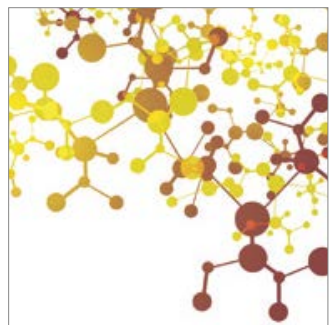

Applied Chemistry
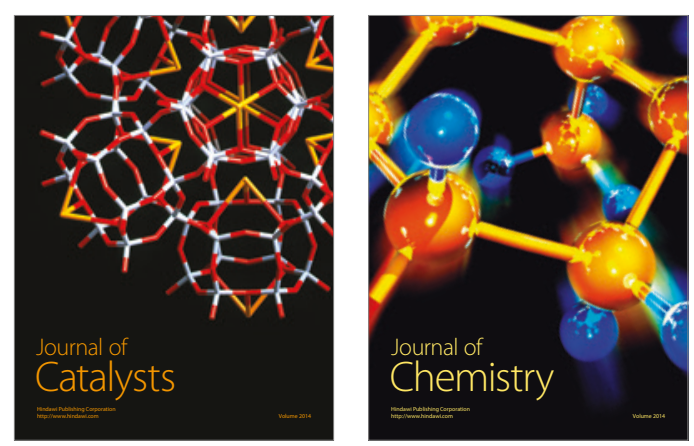
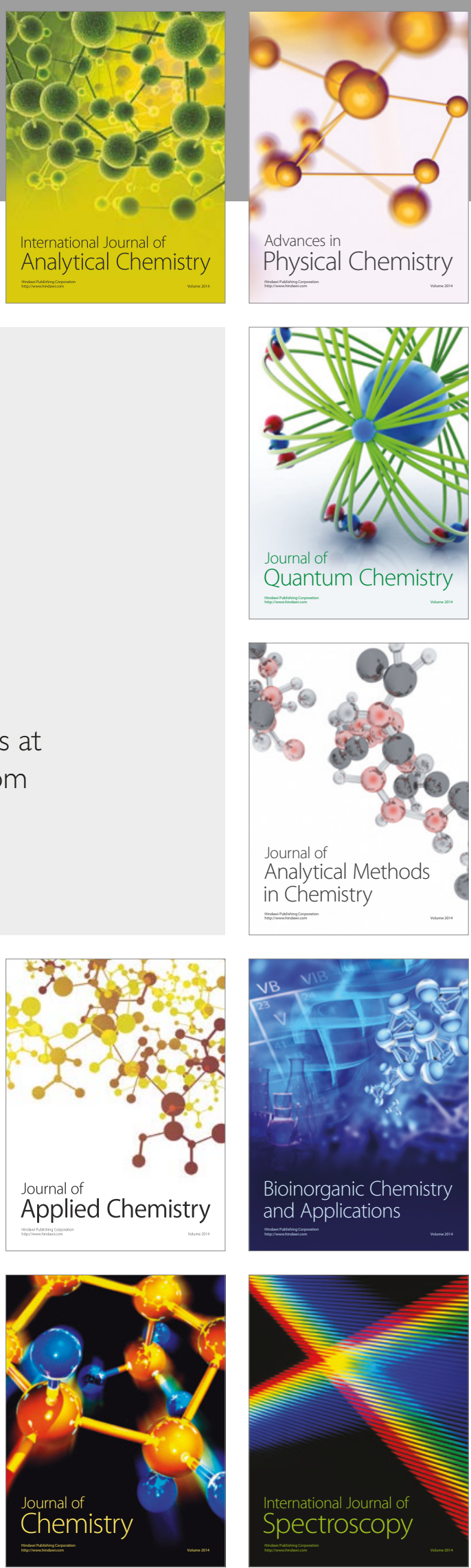